\title{
PREVALENCE OF THE HEPATITIS C VIRUS AMONG UNIVERSITY EMPLOYEES IN SÃO PAULO, SOUTHEASTERN BRAZIL: predictive factors and geoprocessing spatial analysis
}

\author{
Cássio Vieira de OLIVEIRA, Walnei Fernandes BARBOSA, Liciana Vaz de Arruda SILVEIRA, \\ Juliana MENEZES, Flávia Souza MACHADO and Giovanni Faria SILVA
}

\begin{abstract}
Background - There are limited studies on the prevalence and risk factors associated with hepatitis C virus (HCV) infection. Objective - Identify the prevalence and risk factors for HCV infection in university employees of the state of São Paulo, Brazil. Method - Digital serological tests for anti-HCV have been performed in 3153 volunteers. For the application of digital testing was necessary to withdraw a drop of blood through a needlestick. The positive cases were performed for genotyping and RNA. Chisquare and Fisher's exact test were used, with $P$-value $<0.05$ indicating statistical significance. Univariate and multivariate logistic regression were also used. Results - Prevalence of anti-HCV was $0.7 \%$. The risk factors associated with $\mathrm{HCV}$ infection were: age $>40$ years, blood transfusion, injectable drugs, inhalable drugs (InDU), injectable Gluconergam ${ }^{\circledR}$, glass syringes, tattoos, hemodialysis and sexual promiscuity. Age ( $P=0.01$, OR 5.6, CI 1.4 to 22.8$)$, InDU $(P<0.0001, \mathrm{OR}=96.8, \mathrm{CI} 24.1$ to 388.2$)$, Gluconergam ${ }^{\circledR}$ $(P=0.0009, \mathrm{OR}=44.4, \mathrm{CI} 4.7$ to 412.7$)$ and hemodialysis $(P=0.0004, \mathrm{OR}=90.1, \mathrm{CI} 7.5-407.1)$ were independent predictors. Spatial analysis of the prevalence with socioeconomic indices, Gross Domestic Product and Human Development Index by the geoprocessing technique showed no positive correlation. Conclusion - The prevalence of HCV infection was $0.7 \%$. The independent risk factors for $\mathrm{HCV}$ infection were age, InDU, Gluconergan ${ }^{\circledR}$ and hemodialysis. There was no spatial correlation of $\mathrm{HCV}$ prevalence with local economic factors.
\end{abstract}

HEADINGS - Hepacivirus. Spatial analysis. Genotyping techniques.

\section{INTRODUCTION}

Since the isolation of hepatitis $\mathrm{C}$ virus (HCV) complementary DNA in $1989^{(1)}$, hepatitis C has been recognized as a major cause of chronic liver disease throughout the world ${ }^{(9,23)}$. Hepatitis $\mathrm{C}$ prevention and control depend on a complex assessment of $\mathrm{HCV}$ infection global distribution, determination of its associated risk factors and estimation of the factors that accelerate disease progression. In addition, due to the absence of a vaccine or some form of post-exposure prophylaxis, proper epidemiological evaluation is essential for planning primary prevention in any population. HCV infection is characterized by a silent onset that is rarely identified in most patients, although it is highly prevalent.
It also shows a high rate of viral persistence, and chronic infection is asymptomatic in most cases, with the potential to develop end-stage liver disease, such as in the development of chronic hepatitis to cirrhosis and to hepatocellular carcinoma. Due to these features, its natural history is not so precise or clear, which motivates the continuation of studies. HCV infection is a very serious public health problem worldwide. Its global prevalence is of approximately $2.2 \%$ to $3 \%$ of the population, ranging from $0.1 \%$ to $5 \%$ in different countries. It is estimated that approximately 170 million people are chronically infected worldwide and that 3 to 4 million new infections occur each year ${ }^{(15,19)}$. The estimated prevalence rates in specific regions range from $<1 \%$ in Northern Europe to $>2.9 \%$ in Northern 
Africa. The lowest prevalence $(0.01 \%$ to $0.1 \%)$ has been observed in countries of the United Kingdom and Scandinavia, and the highest prevalence rate (15\% to $20 \%)$ has been found in Egypt ${ }^{(15)}$. In Brazil, the prevalence of seropositivity for anti-HCV varies according to the study sample: $1.23 \%$ in blood donors ${ }^{(1)} ; 1.42 \%$ in population samples from São Paulo City ${ }^{(10)}$ and $0.7 \%$ to $2 \%, 1 \%$ in population samples from capital cities ${ }^{(6)}$. The objectives of this study were to determine the prevalence of $\mathrm{HCV}$ infection in a population sample from the state of São Paulo; to identify risk factors for HCV infection; to assess age-specific prevalence and perform the geoprocessing spatial analysis of $\mathrm{HCV}$ infection prevalence correlated with the cities' socioeconomic factors.

\section{SUBJECTS AND METHODS}

The study included 3,153 people (in a universe of 10,776 individuals). They were all university employees and selected by means of direct search in educational campaigns conducted in 17 cities in São Paulo State. Inclusion criteria: university employees who were older than 18 years. Exclusion criteria: age less than 18 years, students, trainees and individuals who were not employees.

\section{Methods}

The volunteers underwent digital serological tests for anti-HCV (HCV rapid test bioassay) after informed consent was obtained. It is based on the immunochromatography method, which had been previously validated by other authors ${ }^{(13,24)}$.

The patients answered a questionnaire with the following risk factors for $\mathrm{HCV}$ infection: age, gender; use of injectable drugs (IDU), inhalable drugs (InDU), energizers (Gluconergan $^{\circledR}$ ), glass syringes, blood transfusions or blood products before 1992; tattooing or piercing, surgical history, occupation in health care, hemodialysis, sexual promiscuity (four or more different sexual partners per year), manicure manipulation. The risk factor for $\mathrm{HCV}$ infection was the common practice of sharing unclean material and not the medication gluconegam itself. At the time of the questionnaire, it was largely informed the subjects.

Patients with positive serological results were referred to the regional referral center for treatment of viral hepatitis. The ELISA test, genotyping and RNA were performed for these patients from collection by the filter-paper technique (dried blood spot sampling) ${ }^{(8,18)}$.

\section{Statistical methodology}

Categorical variables were analyzed by means of absolute and relative frequency tables. Descriptive statistics was used for continuous variables, such as mean, standard deviation, median and extreme values. In order to evaluate the association between $\mathrm{HCV}$ positivity with categorical variables, the chi-square and Fisher's exact test were used, and association was considered to be significant when the $P$-value was $\leq 0.05$.

Univariate and multivariate logistic regression was used to analyze the variables that influenced anti-HCV positivity. The stepwise procedure was performed, and SAS for Windows (Statistical Analysis System), version 6.12 (SAS Institute Inc, USA) was used.

\section{Geoprocessing methodology}

Geoprocessing is the computerized processing of georeferenced data. It employs computer programs that allow for using cartographic information (maps, topographic charts and plans) as a vehicle for spatial data communication.

The system also allows for detecting vulnerable areas in which health problems occur more frequently and severely ${ }^{(9)}$. Geoprocessing is a multidisciplinary science that receives contributions from various fields, such as cartography, computer aided design (CAD) and computer graphics, database management systems (DBMS), remote sensing, artificial intelligence, statistics and informatics.

Spatial analysis can be defined as a technique that seeks to describe patterns existing in spatial data and to establish relationships preferably in a quantitative manner ${ }^{(10)}$. It is basically a signal analysis. Some socioeconomic data population Gross Domestic Product and Human Development Index in the studied cities were correlated with HCV prevalence in their population samples by using spatial representation and mapping systems. Geostatistics was not used due to the fact that the studied sites (cities) were very sparse in the context of the São Paulo State map.

\section{RESULTS}

The overall prevalence was of $0.7 \%$, ranging from $0 \%$ to $2.32 \%$ in the studied cities. Twenty-two cases were found to be positive for anti-HCV. All 22 anti-HCV positive cases for digital tests were confirmed by third-generation ELISA tests, with a $100 \%$ agreement. Genotyping and RNA were also performed, and 21 RNA-positive cases were detected, with predominance of genotype $1(66.6 \%)$ as compared to genotype $3(33.4 \%)$. There was no genotype association with anti-HCV positivity. In the distribution of subjects according to gender, age, BMI and ethnicity, it was found that most of them were females $(54.8 \%)$, white $(83.3 \%)$, overweight (BMI $26.1 \pm 4.5)$ and 40 to 50 years of age $(43.9 \pm 10.2)$.

There was no association of gender or ethnicity with anti-HCV positivity. Regarding the age variable, an association of age $>40$ years with increased risk for anti-HCV positivity was observed (Tables 1 and 2). Increased prevalence was found according to increase in the categorized age ranges studied: 18 to 30 years $(0 \%), 31$ to 40 years $(0.54 \%), 41$ to 50 years $(0.84 \%)$ and $>50$ years $(1.08 \%)$, with a trend towards statistically significant $(P=0.053)$. Association of these following risk factors with HCV positivity was found: blood transfusion, IDU, InDU, previous use of Gluconergam ${ }^{\circledR}$, previous use of glass syringes, hemodialysis, tattooing and sexual promiscuity (Table 2 ).

Logistic regression analysis was performed, and the following were observed as independent risk factors for $\mathrm{HCV}$ infection: age, InDU, Gluconergam ${ }^{\circledR}$ and hemodialysis (Table 3). 
TABLE 1. Characteristics, prevalence and association of anti HCV positive with risk factors of subjects studied ( $\mathrm{n}=3153)$

\begin{tabular}{|c|c|c|c|c|}
\hline Characteristics & n $(\%)$ & Number of anti HCV positive & Prevalence of anti HCV positive & $P+$ \\
\hline Subjects & 3153 & 22 & $0.7 \%$ & \multirow{4}{*}{0.08} \\
\hline Gender & & & & \\
\hline Male & $1407(44.6 \%)$ & 14 & $0.99 \%$ & \\
\hline Female & $1728(54.8 \%)$ & 8 & $0.46 \%$ & \\
\hline Ethinicity & & & & \multirow[t]{4}{*}{0.18} \\
\hline White & $2628(83.3 \%)$ & 17 & $0.64 \%$ & \\
\hline No White & $338(10.7 \%)$ & 5 & $1.47 \%$ & \\
\hline Yellow & $108(3.4 \%)$ & 0 & $0 \%$ & \\
\hline \multicolumn{5}{|l|}{ RiskFactors } \\
\hline Age $>40$ anos & $2024(64.2 \%)$ & 19 & $0.94 \%$ & 0.04 \\
\hline Blood transfusion before 1992 & $88(2.8 \%)$ & 3 & $3.41 \%$ & 0.02 \\
\hline Use of injectable drugs & $8(0.25 \%)$ & 2 & $25 \%$ & 0.001 \\
\hline Use of inhalation drugs & $24(0.76 \%)$ & 5 & $20.85 \%$ & $<0.0001$ \\
\hline Use of Gluconergam $\AA$ & $7(0.22 \%)$ & 3 & $42.86 \%$ & $<0.0001$ \\
\hline Use of a glass syring & $66(2.1 \%)$ & 3 & $4.55 \%$ & 0.01 \\
\hline Tattoo & $189(6 \%)$ & 4 & $2.12 \%$ & 0.03 \\
\hline Piercing & $102(3.2 \%)$ & 0 & $0 \%$ & 0.38 \\
\hline Health professionals & $437(13.85 \%)$ & 2 & $0.46 \%$ & 0.75 \\
\hline Prior surgery & $1779(56.4 \%)$ & 16 & $0.9 \%$ & 0.13 \\
\hline Prior jaundice & $196(6.2 \%)$ & 3 & $1.53 \%$ & 0.15 \\
\hline Hemodialysis & $4(0.13 \%)$ & 1 & $25 \%$ & 0.027 \\
\hline Sexual promiscuity $\dagger$ & $51(1.61 \%)$ & 2 & $3.92 \%$ & 0.048 \\
\hline Manicure & $1101(34.9 \%)$ & 4 & $0.36 \%$ & 0.11 \\
\hline
\end{tabular}

HCV: hepatitis $\mathrm{C}$ virus; $\dagger$ : Four or more sexual partners in 1 year; $\ddagger$ : Fisher’s exact test

TABLE 2. Distribution of Association of hepatitis $C$ virus infection according to sociodemographic characteristics $(n=3153)$

\begin{tabular}{|c|c|c|}
\hline \multirow{3}{*}{ 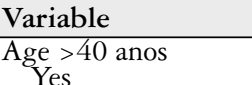 } & Prevalence & $P \$$ \\
\hline & & \\
\hline & $0.94 \%$ & 0.04 \\
\hline No & $0.27 \%$ & \\
\hline \multicolumn{2}{|l|}{ Gender } & 0.08 \\
\hline Male & $0.99 \%$ & \\
\hline Female & $0.46 \%$ & \\
\hline \multicolumn{2}{|l|}{ Ethnicity } & 0.18 \\
\hline White & $0.64 \%$ & \\
\hline No white & $1.47 \%$ & \\
\hline \multirow{2}{*}{\multicolumn{3}{|c|}{ Blood transfusion }} \\
\hline & & \\
\hline Yes & $3.41 \%$ & 0.02 \\
\hline $\begin{array}{l}\text { No } \\
\text { Iniecting drug use }\end{array}$ & $0.62 \%$ & - \\
\hline \multicolumn{3}{|l|}{ Injecting drug use } \\
\hline No & $\begin{array}{l}25 \% \\
0.64 \%\end{array}$ & $\begin{array}{c}0.001 \\
-\end{array}$ \\
\hline \multicolumn{3}{|l|}{ Inhalable drugs use } \\
\hline Yes & $20.83 \%$ & $<0.0001$ \\
\hline \multicolumn{3}{|l|}{ Use of gluconergam ${ }^{\circledR}$} \\
\hline Yes & $42.86 \%$ & $<0.0001$ \\
\hline No & $0.6 \%$ & - \\
\hline \multicolumn{3}{|l|}{ Use of a glass syringe } \\
\hline Yes & $4.55 \%$ & 0.01 \\
\hline $\begin{array}{c}\mathrm{No} \\
\mathrm{Sexu}\end{array}$ & $0.62 \%$ & - \\
\hline \multicolumn{3}{|l|}{ Sexual promiscuity $\dagger$} \\
\hline $\begin{array}{l}\text { Yes } \\
\text { No }\end{array}$ & $3.92 \%$ & 0.048 \\
\hline \multicolumn{3}{|l|}{ Tattoo } \\
\hline Yes & $2.12 \%$ & 0.03 \\
\hline \multirow{2}{*}{\multicolumn{3}{|c|}{ Piercing }} \\
\hline & & \\
\hline Yes & $0 \%$ & - \\
\hline \multirow{2}{*}{\multicolumn{3}{|c|}{ Hemodialysis }} \\
\hline & & \\
\hline $\begin{array}{l}\text { Yes } \\
\text { No }\end{array}$ & $\begin{array}{l}25 \% \\
0.72 \%\end{array}$ & 0.027 \\
\hline \multicolumn{3}{|l|}{ Surgery events } \\
\hline Yes & $0.90 \%$ & 0.13 \\
\hline \multirow{2}{*}{\multicolumn{3}{|c|}{ Jaundice prior }} \\
\hline & & \\
\hline $\begin{array}{l}\text { Yes } \\
\text { No }\end{array}$ & $\begin{array}{l}1.53 \% \\
0.64 \%\end{array}$ & $\begin{array}{c}0.15 \\
-\end{array}$ \\
\hline \multicolumn{3}{|l|}{ Occupational health } \\
\hline Yes & $0.46 \%$ & 0.75 \\
\hline \multirow{2}{*}{\multicolumn{3}{|c|}{ Manicure }} \\
\hline & & \\
\hline $\begin{array}{l}\text { Yes } \\
\text { No }\end{array}$ & $\begin{array}{l}0.30 \% \\
0.88 \%\end{array}$ & 0.11 \\
\hline
\end{tabular}

$\dagger$ : Four or more sexual partners in 1 year; $\ddagger$ : Fisher's exact test
TABLE 3. Independent risk factors* associated for anti hepatitis $C$ virus positive of subjects studied $(\mathrm{n}=3153)$

\begin{tabular}{|c|c|c|c|}
\hline Variable & OR & CI $(95 \%)$ & $P$ \\
\hline Age $>40$ years & 5.6 & $1.4-22.8$ & 0.01 \\
\hline Use of inhalation drug & 96.8 & $24.1-388.2$ & $<0.0001$ \\
\hline Use of Gluconergam ${ }^{\circledR}$ & 44.4 & $4.7-412.7$ & 0.0009 \\
\hline Hemodialysis & 90.1 & $7.5->999,999$ & 0.0004 \\
\hline
\end{tabular}

There was no positive spatial correlation according to geoprocessing analysis (Figures 1 and 2). There was no correlation between socioeconomic data population and the prevalence rate of $\mathrm{HCV}$ in the regions studied.

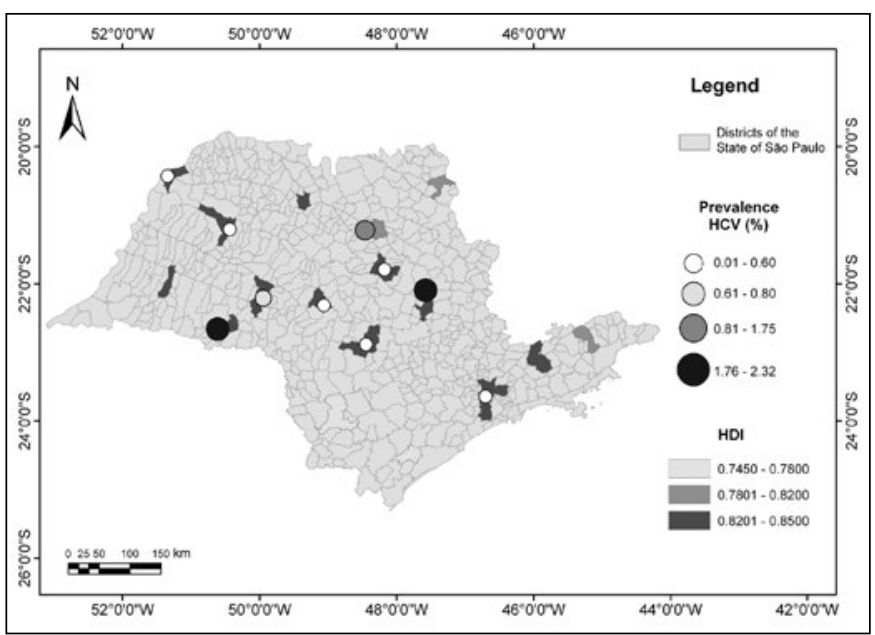

FIGURE 1. Spatial representation of the prevalence of anti-HCV related to the Human Development Index in the cities studied 


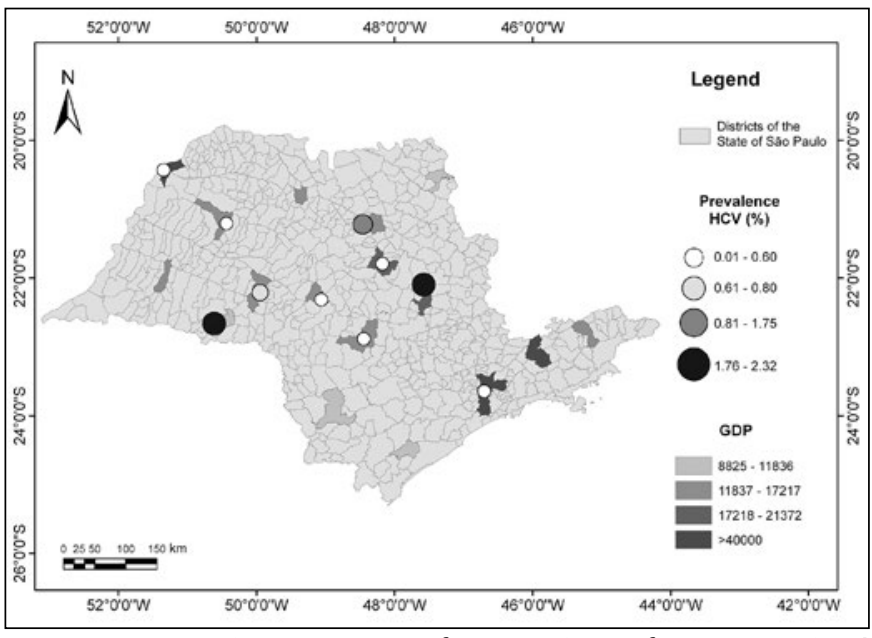

FIGURE 2. Spatial representation of the prevalence of anti-HCV related to the Gross Domestic Product in the cities studied

\section{DISCUSSION}

The group of patients in this study comprised asymptomatic individuals from 17 municipalities in São Paulo State who spontaneously sought the technical health divisions of the university campuses where prevention campaigns and HCV screening tests were performed. Therefore, it does not completely characterize the general population, but allows for analyzing potentially healthy individuals with $\mathrm{HCV}$ infection. On the other hand, a relatively high number of individuals were studied $(n=3,153)$. Prevalence $(0.7 \%)$ was similar to that found in other studies performed on high-risk populations, and the need for screening the entire population, and not only in risk groups, should be considered.

A statistically significant association of positive anti-HCV was shown in individuals aged $>40$ years, which was confirmed as an independent risk factor for HCV infection, thus suggesting an infection pattern that was similar to that found in the United States of America and Australia (an infection contracted in the recent past, 10 to 30 years ago), a fact that was also reported by Focaccia et al. ${ }^{(10)}$ when studying a population sample from São Paulo.

In the sample studied, only $0.25 \%$ of individuals reported IDU, although $25 \%$ of these confirmed positivity for anti-HCV, and an association was observed between IDU and $\mathrm{HCV}$ infection. In Brazil, IDU as a risk factor for $\mathrm{HCV}$ infection is reported with variable frequency in several studies $^{(5,17)}$. In the United States of America, studies ${ }^{(14)}$ reported IDU in $51 \%$ of their subjects comprising their samples, which consisted of blood donors. It is important to emphasize the fact that a considerable number of employees may have denied past IDU in completing the questionnaire and during the interview for fear of discrimination, although they were informed about the confidentiality of information. This occurrence was also reported by Thomas ${ }^{(20)}$ in an editorial.

The use of inhalable drugs, particularly cocaine, has been associated with $\mathrm{VHC}$ infection ${ }^{(7,22)}$, but that route is not consensually accepted as a form of infection transmission ${ }^{(21)}$. Alter et al. ${ }^{(2)}$, when interviewing users of cocaine inhalation, reported that approximately 30\% reported epistaxis during inhaling, and another $30 \%$ observed nose bleeding in their mates. Therefore, this contamination route appears to be biologically feasible when "straw" sharing by users occurs, especially in those showing epistaxis. In our subjects, the association of a history of inhalable drug use was shown as an independent risk factor for HCV infection.

Gluconergam $^{\circledR}$ consists of the following substances: glucose, vitamin $\mathrm{C}$ and 2-Amino-5-guanidinovaleric acid hydrochloride. It used to be prescribed as a tonic, and its use was intended to promote better performance in sports and carnival balls. This medication has been banned in the Brazilian market for several years. In these subjects, this factor was associated with risk for HCV positivity, which was confirmed by logistic regression analysis and also shown by Silva et al. ${ }^{(16)}$.

A history of glass syringe use was considered a possible risk factor for $\mathrm{HCV}$ infection because this practice, without safe sterilization, was common in Brazil in the past. The risk of association found in the sample studied by Fisher's exact test was not observed after logistic regression analysis.

The pattern for HCV genotype distribution found in this study was similar to that in other studies previously conducted in $\operatorname{Brazil}^{(5,11,12,17)}$.

In an unprecedented manner in Brazil, the geoprocessing technique was applied in hepatitis $\mathrm{C}$ studies by using the spatial representation of $\mathrm{HCV}$ infection prevalence correlated with socioeconomic factors in the studied cities. Although there was no positive spatial correlation, this analysis can serve as a stimulus for further studies in this field.

Soon after its identification, several epidemiological studies failed to relate $\mathrm{HCV}$ to a contamination route in up to $40 \%$ of cases. Alter ${ }^{(4)}$ associated it with low socioeconomic development in $44 \%$ of individuals. More recently, the same author and colleagues ${ }^{(3)}$ still associate it with poverty as an independent factor. One hypothesis is that there may be lack of knowledge about some means of $\mathrm{HCV}$ infection, such as shares of domestic objects, in populations of low socio economic level. There are no reports in the literature of studies investigating such association using the geoprocessing technique.

\section{CONCLUSION}

The prevalence of $\mathrm{HCV}$ infection in the studied sample was $0.7 \%$, with variation for the studied cities. The risk factors associated with $\mathrm{HCV}$ infection were blood transfusion before 1993, IDU, InDU, gluconergam ${ }^{\circledR}$ use, glass syringes, hemodialysis, tattooing and sexual promiscuity. The independent risk factors for $\mathrm{HCV}$ infection were age, inhalable drugs use, Gluconergam ${ }^{\circledR}$ use and hemodialysis. No spatial correlation of HCV prevalence with the cities' socioeconomic factors was observed in the studied sample.

\section{Author contribution}

Oliveira CV coordinated this study and participated in the data collection and compilation of the text, Barbosa WF, Silveira LVA, Menezes J e Machado FS participated in the compilation of the text, Silva GF participated in the coordination and compilation of the text. 
Oliveira CV, Basbosa WF, Silveira LVA, Menezes J, Machado FS, Silva GF. Prevalência do vírus da hepatite C em funcionários universitários do Estado de São Paulo, Brasil: fatores preditivos e análise espacial por geoprocessamento. Arq Gastroenterol. 2015,52(1):9-13.

RESUMO - Contexto - Existem escassos estudos sobre a prevalência e fatores de risco associados à infecção pelo vírus da hepatite C. Objetivos - Identificar a prevalência e os fatores de risco para a infecção pelo vírus da hepatite C em funcionários de uma Universidade do Estado de São Paulo, Brasil. Métodos - Testes sorológicos digitais para anti vírus da hepatite $\mathrm{C}$ foram realizados em 3.153 voluntários. Para a aplicação do teste digital foi necessário retirar uma gota de sangue através de uma picada de agulha. Nos casos positivos foram realizados genotipagem e RNA. Os testes Qui-quadrado e exato de Fisher foram utilizados, com valor de $P<0,05$ sendo considerado como estatisticamente significante. Regressão logística univariada e multivariada também foram aplicadas. Resultados - A prevalência de anti vírus da hepatite $\mathrm{C}$ foi de $0,7 \%$. Os fatores de risco associados com a infecção pelo vírus da hepatite $\mathrm{C}$ foram idade $>40$ anos, transfusão de sangue, uso de drogas injetáveis, uso de drogas inalatórias, Gluconergam ${ }^{8}$ injetável, uso de seringas de vidro, tatuagens, hemodiálise e promiscuidade sexual. Idade $(P=0,01$, OR 5,6, IC 1,4-22,8), uso de drogas inalatórias $(P<0,0001, \mathrm{OR}=96,8, \mathrm{IC} 24,1-388,2)$, Gluconergam ${ }^{\circledR}$ injetável $(P=0,0009, \mathrm{OR}=44,4, \mathrm{IC} 4,7-412,7)$ e hemodiálise $(P=0,0004, \mathrm{OR}=90,1, \mathrm{IC} 7,5-407,1)$ foram preditores independentes. A análise espacial da prevalência com índices socioeconômicos, produto interno bruto e índice de desenvolvimento humano, por meio da técnica de geoprocessamento, não mostrou correlação positiva. Conclusões - A prevalência da infecção pelo vírus da hepatite C foi de $0,7 \%$. Os fatores de risco independentes para a infecção pelo vírus da hepatite $\mathrm{C}$ foram idade, uso de drogas inalatórias, Gluconergan ${ }^{\circledR}$ injetável e hemodiálise. Não houve correlação espacial da prevalência de vírus da hepatite $\mathrm{C}$ com fatores econômicos locais.

DESCRITORES - Hepacivirus. Análise espacial. Técnicas de genotipagem.

\section{REFERENCES}

1. Ackerman Z, Ackerman E, Paltiel O. Intrafamilial transmission of hepatitis $\mathrm{C}$ virus: a systematic review. J Viral Hepat. 2000;7(2):93-103.

2. Alter HJ, Conry-Cantilena C, Melpoder J, Tan D, Van Raden M, Herion D, et al. Hepatitis C in asymptomatic blood Donors. Hepatology. 1997;26(3 suppl 1):29S-33S.

3. Alter HJ, Seeff LB. Recovery, persistence, and sequelae in hepatitis C virus infection: a perspective on long-term outcome. Semin Liver Dis. 2000;20(1):17-35.

4. Alter MJ. Epidemiology of hepatitis in the West. Semin Liver Dis. 1995;15(1):5-14

5. Bassit L, Vanderborght B, Dorlhiac-Llac PE, Chamon DAF, et al. Anti-HCV PCR positivity subtypes among screening positive blood donors from São Paulo. Rev Soc Bras Med Trop. 1994;27(suppl.1):100.

6. Brasil. Ministério da Saúde, Protocolo Clínico e Diretrizes Terapêuticas para Hepatite Viral C e Coinfecções. Brasília. Secretaria de Vigilância em Saúde Departamento de DST, Aids e Hepatites Virais, 2011. p.1-103.

7. Conry-Cantilena C, VanRaden M, Gibble J, Melpoder J, Shakil AO, Viladomiu L, et al. Routes of infection: viremia, and liver disease in blood donors found to have hepatitis C virus infection. N Engl J Med. 1996;334(26):1691-6.

8. Croom HA, Richards KM, Best SJ, Francis BH, Johnson EI, Dax EM, Wilson KM. Commercial enzyme immunoassay adapted for the detection of antibodies to hepatitis C virus in dried blood spots. J Clin Virol. 2006;36(1):68-72.

9. EASL International Consensus Conference on Hepatitis C. Paris, 26-28, February 1999, Consensus statement. J Hepatol. 1999;30:956-61.

10. Focaccia R, da Conceição OJ, Sette H Jr, Sabino E, Bassit L, Nitrini DR, et al. Estimated prevalence of viral hepatitis in General Population of the municipality of São Paulo, measured by a serologic survey of a stratified, randomized and residence-based population. Braz J Infect Dis. 1998;2(6):269-84.

11. Fonseca J. [Epidemiologia da infecção pelo vírus da hepatite $\mathrm{C}$ no Brasil. Relatório do Grupo de Estudo da Sociedade Brasileira de Hepatologia]. GED. 1999;18(suppl 1):S3-S8

12. Germano FN, dos Santos CA, Honscha G, Strasburg A, Gabbi B, Mendoza-Sassi $\mathrm{RA}$, et al. Prevalence of hepatitis $\mathrm{C}$ virus among users Attending the voluntary testing center in Rio Grande, southern Brazil: predictive factors and hepatitis $\mathrm{C}$ virus genotypes. Int J STD AIDS. 2010;21(7):466-71.
13. Grakoui A, Wychowski C, Lin C, Feinstone SM, Rice CM. Expression and identification of hepatitis C virus polyprotein clevage products. J Virol. 1993 67(3):1385-95.

14. Murphy EL, Bryzman SM, Glynn SA, Ameti DI, Thomson RA, Williams AE, et al. Risck factors for hepatitis C virus infection in United States blood donors. Hepatology. 2000;31(3):756-62.

15. Shepard CW, Finelli L, Alter MJ. Global epidemiology of hepatitis C virus infection. B Lancet Infect Dis. 2005;5(9):558-67.

16. Silva GF, Nishimura NC, Caramori C, Soares JV. Influence of a regional habit on the hepatitis $\mathrm{C}$ virus infection: the role of gluconergan. Hepatology. 2001;34(4):574A.

17. Silva GF, Nishimura NF, Coelho KI, Soares EC. Grading and staging of chronic hepatitis $\mathrm{C}$ and Its relation to genotypes and epidemiological factors in Brazilian blood donors. Braz J Infect Dis. 2005;9(2):142-14.

18. Solmone M, Girardi E, Costa F, Pucillo L, Ippolito G, Capobianchi MR. Simple and Reliable Method for Detection and Genotyping of Hepatitis C Virus RNA in Dried Blood Spots Stored at Room Temperature. J Clin Microbiol. 2002;40(9):3512-4.

19. Sy T, Jamal MM. Epidemiology of hepatitis $\mathrm{C}$ virus (HCV) infection. Int J Med Sci. 2006,3(2):41-6.

20. Thomaz DL. Hepatitis C epidemiology: injecting new tools in the field. Hepatology. 2000;31(3):790-1.

21. Wasley AM, Alter MJ. Epidemiology of hepatitis C: geographic differences and temporal trends. Semin Liver Dis. 2000;20(1):1-16.

22. Willians IT, Sabin K, Fleenor M, Judson F, Mottram K, Pougade J, et al. Current patterns of hepatitis $\mathrm{C}$ virus transmission in the United States: the role of drugs and sex. Hepatology. 1998;(Suppl 2) 28 (4):S1337-S40.

23. World Health Organization (WHO). Hepatitis C - global prevalence. Weekly Epidemiological Record. 1997;72:341-4.

24. Yoshikawa A, Takahashi K, Kishimoto S, Tsuda F, Akahane Y, Naito S. Serodiagnosis of hepatitis $\mathrm{C}$ virus infection by ELISA for antibodies against the putative core protein (P20C) Expressed in Escherichia coli. J Immunol Methods. 1992;148(1-2):143-50.

Received 30/3/2014 Accepted 29/5/2014 